\title{
Mechanistic models supporting uncertainty quantification of water quality predictions in heterogeneous mining waste rocks: a review
}

\author{
Muhammad Muniruzzaman ${ }^{1}$ (D) Daniele Pedretti ${ }^{2}$ \\ Accepted: 23 September 2020 / Published online: 1 October 2020 \\ (C) The Author(s) 2020
}

\begin{abstract}
Polluted drainage from weathering of sulfide-rich waste rock deposits can cause long-term impairment to waterways and biodiversity near mining sites. Mechanistic models represent established tools to support the predictions of the quantity and quality of waste rock drainage, and their associated risks. Yet, model-based predictions in typical waste rock systems are ubiquitously uncertain because of the strongly heterogeneous nature of these waste deposits. Embedding heterogeneity within predictive modeling is complicated by the magnitude and level of knowledge of the waste rock heterogeneity, and the large number of scale-dependent parameters feeding the model equations. This review encompasses deterministic and stochastic modeling approaches that emphasize consolidated tools and emerging modeling solutions to deal with heterogeneity for the modeling of waste rocks. Physical (e.g., variability of texture, hydraulic and pneumatic properties), geochemical (e.g., variability of mineralogy and kinetic parameters), and thermal heterogeneities are evaluated. The review points out the importance of stochastic modeling as a fundamental approach to embed uncertainty in long-term modelbased decisions. Regulators and decision makers must be convinced of the benefit of using stochastic modeling, which is still considered to belong mainly to the academic sphere.
\end{abstract}

Keywords Waste rocks · Heterogeneity · Mechanistic modeling · Stochastic modeling · Acid mine drainage · Reactive transport modeling

\section{Introduction}

Mine waste management represents one of the biggest environmental and socio-economic concerns for mining operators, governments and citizens. A critical concern is related to the weathering of sulfide-rich mining byproducts such as waste rocks and tailings, which can generate a toxic leachate enriched in metals and metalloids. This drainage is very often called acid rock drainage (ARD). The formation, fate and management of ARD, including passive and active remediation approaches, has been addressed in multiple

Daniele Pedretti

daniele.pedretti@unimi.it

Muhammad Muniruzzaman

md.muniruzzaman@gtk.fi

1 Geological Survey of Finland, Vuorimiehentie 5, 02151 Espoo, Finland

2 Dipartimento di Scienze della Terra “A. Desio”, Università degli Studi di Milano, 20133 Milan, Italy reviews (Blowes et al. 2003; Dold 2017; Muniruzzaman et al. 2018; Nordstrom et al. 2015; Nordstrom and Alpers 1999; Plumlee 1999; Wolkersdorfer et al. 2020; Wolkersdorfer and Bowell 2004), guidelines (EPA 1994; European Commission 2009; INAP-GARD 2014; MEND 1998; Price 2009; Sobek et al. 1978) and books (Blowes et al. 2014; Lottermoser 2010).

The deleterious impact of ARD on water resources, and in turn on public health and aquatic ecosystems, is well known and studied. From a health risk perspective, ARDcontaminated water supplies, such as pumping wells (Christenson 1995), can expose the population to elevated concentrations of metal(loid)s, such as lead $(\mathrm{Pb})$, arsenic (As), manganese (Mn), and cadmium (Cd). Excess of metal(loids) has been linked to multiple physiological alterations, e.g. neurological alteration, kidney disease, chronic obstructive pulmonary disease, hypertension and heart disease (Neuberger et al. 2009; Wright et al. 2006). The transport of ARD to water resources affects aquatic ecosystems by a number of direct and indirect pathways, 
which include habitat modification, niche loss, bioaccumulation within the food chain, loss of food sources, elimination of sensitive species, reduction in primary productivity, and food chain modification (Betrie et al. 2016; Gray 1997).

Waste rocks are among the most common forms of mine waste. Amos et al. (2015) extensively reviewed the physical and mineralogical characteristics of waste rock piles, providing a list of the principal processes related to sulfide oxidation and solute loading. They concluded with a discussion on acid mine drainage prediction and prevention techniques, which included mechanistic model based analyses. Amos et al. (2015) indicated in particular that "numerical models will provide a valuable tool to incorporating greater complexity and mechanistic process description into leach water quality predictions".

Model-based predictions of ARD from waste rocks are severely complicated by the presence of spatially variable physical and biogeochemical properties. A conceptualization of the type of heterogeneities that this paper tackles is shown in Fig. 1: (a) physical heterogeneity controls the movement of water and associated solute dynamics in ARD-generating environments; (b) biological and geochemical heterogeneity affect the reactions involving gas, water and minerals, with biota as the catalyzers of geochemical processes, during the formation and evolution of ARD plumes; (c) thermal and pneumatic heterogeneity have strong influence on more specific aspects, such as mechanisms sustaining the supply of oxygen towards oxidizing sites. Note that the ARD-receiving environment could also be a heterogeneous system, such as an alluvial aquifer (Fig. 1) or a fractured aquifer.

Heterogeneity generates uncertainty in the parameters feeding mechanistic models used to make predictions of ARD from waste rock. Consequently, these model-based predictions are bound to be uncertain in a system without adequately resolving the magnitude of the involved heterogeneity. While stochastic modeling is an appropriate framework to deal with heterogeneity-driven uncertainty in hydrogeological problems (Freeze 2004; Guadagnini and

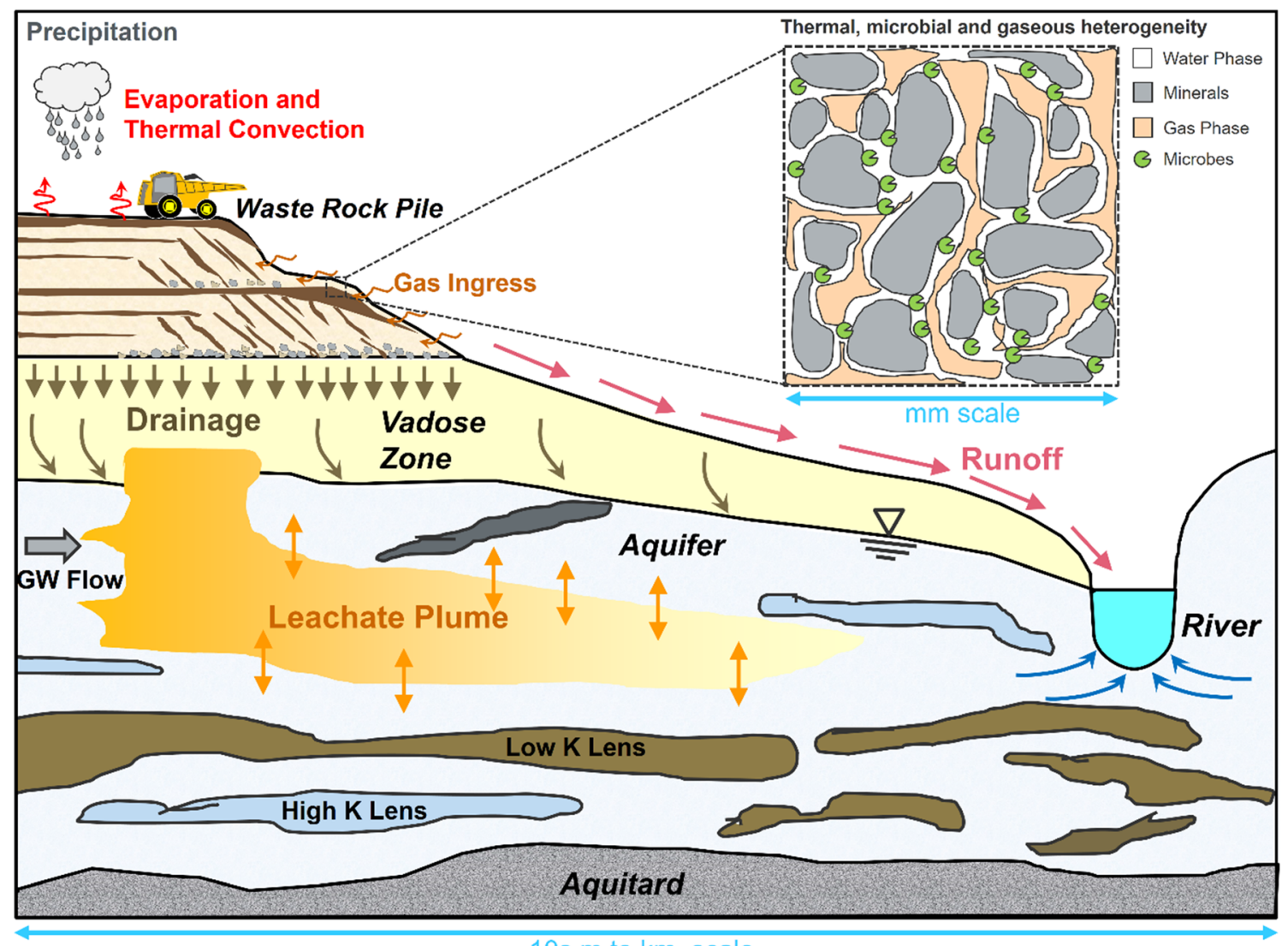

$10 \mathrm{~s} \mathrm{~m}$ to $\mathrm{km}$ scale

Fig. 1 Schematic diagram illustrating the generation of acid rock drainage and the subsequent propagation of leachate from waste rocks (as piles) to a receiving environment (groundwater aquifer and surface water bodies). In the overburden pile, darker colour represents the compacted fine-grained materials whereas the light colour represents coarse waste rock material. The inset illustrates heterogeneity associated with the water-gas-solid phases as well as bacterial species at pore-scale. The drainage from the pile percolates to the aquifer, which can be also a heterogeneous system, with spatially variable hydraulic properties, such as the hydraulic conductivity $(K)$ 
Tartakovsky 2010; Lichtner and Tartakovsky 2003; Rubin et al. 1994; Serre et al. 2003), the use of stochastic models for waste rocks modeling is still limited. From the perspective of mine waste simulations, even the deterministic models embedding heterogeneity has been also rarely developed. A main reason is that ARD from waste rocks is controlled by multidimensional multiphase coupled processes described by strongly nonlinear partial differential equations. Intense computational efforts must be considered when resolving heterogeneous waste rock simulations. The development of multicore workstations, parallel computing and access to supercomputers is rapidly changing this scenario, particularly regarding stochastic modeling.

The purpose of this work is to fill a gap in the current literature by presenting a review of the evolution of the approaches that can be used to improve waste-rock modeling considering heterogeneity as a complicating factor for the model predictions. In the first part of the paper, we address an overview of the mechanistic approaches that have been adopted so far for long-term predictions of ARD from heterogeneous waste rocks. This includes both deterministic and stochastic models. Secondly, we present our perspective regarding how the discipline could evolve to increasingly include heterogeneity in future ARD studies. We emphasize the importance of embedding stochastic heterogeneity for risk assessment and other type of studies that require an explicit simulation of heterogeneity as a driver of model uncertainty.

With this review, we aim at providing the reader with a better understanding of model-based tools that can be used to quantify, control or reduce the heterogeneity-driven uncertainty regarding the predictions of the deleterious impact of ARD on water resources. The review targets researchers and technicians, particularly hydrogeological and geochemical modelers, as well as mining practitioners and operators. A goal of this work is to illustrate that the use of heterogeneous modeling is no longer prohibitive, as it could have been just one decade ago: nowadays, modeling is facilitated by easier-than-ever-before accessibility to powerful workstations, super-computers and other solutions for parallel computing, which require simple notions of programming skills to be pre and post-processed. In this sense, heterogeneity-driven uncertainty can be explicitly quantified by modelers and the results presented to decision makers in the form of probabilistic results.

The review assumes that the reader is already familiar with basic elements and processes influencing ARD in waste rocks as well as basic corollary notions associated to mine waste management, such as depositional methods to create waste-rock deposits. Specific information on ARD formation and attenuation mechanisms can be found in a wealth of scientific articles, books and reviews-e.g. about pyrite oxidation mechanisms (Battistel et al. 2019; Evangelou and Zhang 1995; Rimstidt and Vaughan 2003), about the formation of iron and aluminum hydroxysulfates (Bigham and Nordstrom 2000), about mineralogical assemblage (Parbhakar-Fox and Lottermoser 2015), about methods to remediate ARD (Akcil and Koldas 2006; Johnson and Hallberg 2005; Sheoran and Sheoran 2006; Tripathy 2014) or about biologically-related processes (Baker and Banfield 2003; Nordstrom and Southam 1997; Papirio et al. 2013). Ultimately, it is assumed that the reader also possesses notions of flow and reactive transport modeling in porous and fractured media. Steefel et al. (2014) provides a comprehensive review of reactive transport modeling in subsurface environments.

\section{Evolution of mechanistic modeling for heterogeneous waste rocks}

This section revises some of the key mechanistic (i.e. process-based) models that have deterministically incorporated heterogeneity in their formulations or been used to compute ARD from waste rocks using heterogeneous parametrizations. While not all the revised models have been used for quantifying the heterogeneity-driven uncertainty in ARD predictions, these models could be used for this purpose. Indeed, most of them provide the basis for rigorous uncertainty quantification analysis, as addressed in the following Sect. 3.

\subsection{First models}

Influential initial contributions were the breakthrough studies by Davis et al. (1986); Davis and Ritchie (1987, 1986). They presented a set of model formulations of pyritic oxidation in mine wastes that incorporated the assumptions of a previous simpler model (Ritchie 1977) and coupled the effect of transport of oxygen into the particles comprising the waste rock deposit with transport through the pore space of the waste rocks. While their study was based on diffusive gas transport only, they first presented (Davis and Ritchie 1986) the general formulations of the model and a simplifying assumption which made it possible to resolve the problem analytically. The approximated analytical model was then tested numerically (Davis et al. 1986). As the previous models were based on single-size particle radii, in a follow-up study (Davis and Ritchie 1987) they extended the model to evaluate a range of particle sizes in the waste rocks, which is a more realistic description of true waste rock piles. A central equation is the 1-D diffusion equation for gaseous oxygen in the waste rocks, with the form: 
$\phi \frac{\partial C_{\text {pores }}}{\partial t}=D_{g} \frac{\partial^{2} C_{\text {pores }}}{\partial x^{2}}-q$

where $x$ is the spatial coordinate, $t$ is time, $\phi$ is the porosity of the waste rock, $C_{\text {pores }}$ is the oxygen concentration within the pore space, $D_{g}$ is the diffusion coefficient of gaseous oxygen in pore space, and $q$ is a source-sink term that account for the mass transfer between the pore spaces and the reactive minerals, with the form:

$q=\int_{a_{0}}^{a_{n}} 4 \pi a^{2} C_{p a r t} D_{w} \frac{\partial C_{\text {part }}}{\partial r} f(a) d a$

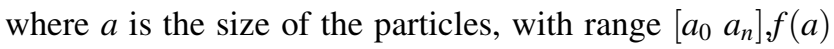
is the density of particles between $a$ and $\mathrm{d} a, C_{\text {part }}$ is the oxygen concentration within the reactive particle, and $D_{w}$ is the diffusion coefficient of aqueous oxygen in water. These expressions are then included into the general reactive transport model (Davis and Ritchie 1986) to compute sulfide leaching rate and heat generation from the exothermic oxidation of sulfides. The model, called "distributed particle size model (DPM)", is one of the first documented heterogeneous reactive transport models for waste rocks.

In Davis and Ritchie (1987), the DPM was used to simulate weathering of an idealized waste rock system with parameterization inspired on the White's waste rock piles at Rum Jungle in the Northern Territory of Australia (Davis and Ritchie 1986). The pyritic waste material was characterized by a pyrite content of $3.3 \%$, a porosity of 0.4 , an oxygen diffusion coefficient through the pore space of $6.72 \times 10^{-6} \mathrm{~m}^{2} \mathrm{~s}^{-1}$, and depth of $18 \mathrm{~m}$. A distribution of particles spanning between 1 and $200 \mathrm{~mm}$ was adopted, with a larger number of particles corresponding to the larger sizes and with half the mass composed of particles with radii less than approximately $32 \mathrm{~mm}$. The DPM results were compared against the results of two equivalent homogeneous models embedding respectively particle sized of 10 and $50 \mathrm{~mm}$. Davis and Ritchie (1987) found that the heterogeneous DPM generated a drastic difference in the model results compared to the homogeneous models. While the latter could still be accurate for predictive purposes of sulfate production rates at specific time scales and for the tested conditions, predicted heat source distribution at 26 years was sensibly impacted by the selected particles distributions. The authors concluded that it was "essential" to include the particle size distribution (i.e. heterogeneity) in the model.

Since Davis and Ritchie (1987), several other mechanistic modeling formulations and analyses have followed. The vast majority of research on ARD modeling from waste rocks has focused on numerical modeling, with a few notable exceptions where analytical solutions were obtained (Binning et al. 2007). The rapid development of numerical models was promoted on the one hand by the increasingly high power and low costs of computational machines, and on the other hand by the increasing awareness of the importance of embedding heterogeneities for model predictions (heterogeneity is hardly embedded into analytical solutions). Nowadays, multiphase multicomponent reactive transport models are able to simulate a wide range of processes, including both advective and diffusive gas transport, the effects of oxidizing agents in contact with sulfidic materials and the interaction between minerals and pore-fluids (da Silva et al. 2009; Ma et al. 2019; Mayer et al. 2015; Molson et al. 2005; Muniruzzaman et al. 2020; Sracek et al. 2004; Wang et al. 2019).

\subsection{Models embedding physical heterogeneity}

Flow and transport heterogeneity in waste rock deposits are primarily controlled by the inhomogeneous spatial distribution of textural properties controlling water infiltration and seepage through the subsurface, and the associated advective and dispersive mechanism of solutes. The degree of heterogeneity depends on natural heterogeneity of the background of the deposits from which the mine waste has been generated and the additional physical heterogeneity created by the artificial alternation of the ore deposits, for instance through blasting, milling, dumping and layering (Bailey et al. 2013; Day 1994; Smith et al. 1995; Smith and Beckie 2003). For instance, end-dumping deposition (Blackmore et al. 2014; Peterson 2014; St-Arnault et al. 2020; Vriens et al. 2019) results in material segregation with coarser material falling for larger distances than the fine particles, which remain on top of the dumping sequence or pile. The sequencing of dumping stages determine a layering structure with compacted traffic surface embedded among the dumps lifts (Lefebvre et al. 2001a, b).

The selection of the most-suitable modeling approach to reproduce and predict flow and transport heterogeneity in waste rocks is not a simple choice and it is still a debated issue. A critical initial element to consider is the importance of capillary and non-capillary flow. So far, mechanistic models for flow in waste rocks have mostly relied on the concept of equivalent porous media, in which continuum approaches based on the Darcy's equation are valid and characterized by properties such as the hydraulic conductivity $(K)$ and the porosity $(\phi)$. Since waste rocks are unsaturated systems, the majority of waste rock models presented so far have been based on single-porosity capillary-based Richards (1931) equation, in which the key parameterization is based on soil-water characteristic curves (SWCCs) and relative permeability (HF) functions. In general, this approach is valid when the waste rocks 
have a "soil-like" regime, where flow is generally homogeneously rinsing the waste rocks, resulting in a matrixcontrolled flow pattern. An increasing number of studies have found that flow in coarse-textured waste rocks may be still dominated by capillarity and matrix dominated water flow and transport (Appels et al. 2018; Eriksson and Destouni 1997; Neuner et al. 2013).

The importance of combining textural heterogeneity and hydrological regimes to properly understand flow in waste rocks is well known. Newman et al. (1997), for instance, developed a 2-D deterministic two-column model embedding two distinct materials, a fine-grained soil and a coarse layer soil. Adopting a finite element code based on a single-porosity version of the Richards equation, Newman et al. (1997) showed that the type of material where infiltrating water preferentially travels through is strongly controlled not only by the soil texture but also by the rainfall regime and the selected SWCCs and HFs for the two materials. Under heavy rainfall, the influx rate at the model top boundary exceed the infiltration capacity of the fine-grained material and water enters preferentially the coarse-grained materials. Under light rainfall, the material enters preferentially the fine-grained material which has (under unsaturated conditions) a higher relative permeability than the coarse-grained material.

Strong contrasts in textures can result in more pronounced preferential channels embedded into a less permeable matrix. Multiple studies (e.g. Blackmore et al. $2018,2014)$ have suggested that the presence of non-capillary-driven flow can significantly complicate the processes conducting recharging through the pore space similar to what occurs for instance in structured soils (Beven and Germann 2013; Simunek et al. 2003). When preferential flow dominates the waste rock's seepage regime, only a few zones can collect majority of the infiltrating water within the deposits (Nichol et al. 2005). Morin and Hutt (2008) suggested that as little as 5\% of the entire mine deposit may be actually rinsed by the infiltrating water. In the Diavik experimental waste rocks, Neuner et al. (2013) reported that the porosity $(\phi)$ of the bulk waste rock in the test piles is estimated to be $\phi=0.24$, the void or macropore porosity is estimated to be $\phi=0.18$, while the pore space affected by capillarity is approximately the remaining of the bulk volume of the test piles.

The heterogeneity in the flow distribution affects directly advective and dispersive transport mechanisms of solutes (as well as reactions, as described in detail in the next sections) in waste rocks. Internal and external tracer tests have been widely used to elucidate the implication of preferential flow in heterogeneous waste rocks, and the type of models to be selected. The presence of "dead pores" largely conditions the fate of a conservative tracer within saturated waste rock (Murr 1979). Wetting front velocities in coarse heterogeneous material travel several orders of magnitude faster than the mean water velocity in granular waste rocks (Nichol et al. 2005; Webb et al. 2008). Internal tracers, in particular blasting residuals, have been also adopted to characterize heterogeneous mine waste deposits (Bailey et al. 2013; Blackmore et al. 2018; Hendry et al. 2018; Mahmood et al. 2017). At the Antamina waste rock experimental site, Blackmore et al. (2018) found that, while a waste rock pile characterized by coarse-grained materials shows rapid flow and long tailing in the estimated breakthrough curves (BTCs) for the externally injected and internal tracers, the finer grained pile also shows clear tailing on both tracers' BTCs. At the Aitik mine in Sweden, Eriksson et al. (1997) estimated that flow and transport could have accounted preferentially for about $55-70 \%$ of the total water content in the local waste rocks.

Modeling solute transport in heterogeneous waste rocks can be done in multiple forms. One option is through multidimensional models that explicitly simulate the variability of textural properties of the waste rocks. Molson et al. (2005) presented one of the first examples in this sense by coupling the models presented by Fala et al. (2005) to POLYMIN (Molson et al. 2004), a reactive mass transport and sulfide oxidation model based on the wellknown multicomponent geochemical model (Allison et al. 1991) (this code is also described in the next section for what concerns its reactive modeling capabilities). They showed that solute transport tends to channel along the preferential flow created by flow instabilities. In real site, these instabilities, correspond to flow channels, would occur naturally due to intrinsic heterogeneities in the materials and along the interface and also due to pore-scale variations in the moisture content. Another possible modeling approach is based on an effective (or lumped) parameterization of the 1-D advection-dispersion equation, which can account for multiple porosities, each one characterized by a specific water mobility (Simunek et al. 2003). Blackmore et al. (2018) used the dual-porosity version of HYDRUS-1D (Simunek et al. 2005) to fit multiple tracer tests in two waste rock experimental piles in Antamina concluding that a possible conceptual model for transport in waste rocks would consist of at least three porosity components:

(1) a porosity associated with fast-flow channels, activated under strong recharge events;

(2) a porosity associated with a slower-flow matrix material, activated or controlled by natural rainfall events;

(3) a no-flow porosity, i.e. the immobile domain, in which transport occurs through diffusive processes only. 


\subsection{Models embedding geochemical heterogeneity}

Polluted drainage from mining waste deposits involves acidic, circumneutral or basic aqueous conditions. Likely, the most common of the geochemical process causing ARD is the weathering of potentially acid generating minerals (PAGs) and in particular sulfides. PAGs oxidation triggers several other processes, such as metal leaching or carbonate and silicate dissolution to compensate water acidity. The weathering rate of PAGs depends on multiple aspects such as textural properties of the minerals, the presence of water and oxidizing agents (mainly oxygen) existing or supplied to the reactive sites and the presence of acidophilic bacteria. For instance, pyrite oxidation can be described through the following reactions (Harries and Ritchie 1981):

$$
\begin{aligned}
& \mathrm{FeS}_{2}+3.50 \mathrm{O}_{2}+\mathrm{H}_{2} \mathrm{O} \rightarrow \mathrm{Fe}^{2+}+2 \mathrm{SO}_{4}^{2-}+2 \mathrm{H}^{+} \\
& \quad \Delta \mathrm{H}=1440 \mathrm{~kJ} \mathrm{~mol}^{-1} \\
& \mathrm{Fe}^{2+}+0.25 \mathrm{O}_{2}+\mathrm{H}^{+} \rightarrow \mathrm{Fe}^{3+}+0.50 \mathrm{H}_{2} \mathrm{O} \\
& \quad \Delta \mathrm{H}=102 \mathrm{~kJ} \mathrm{~mol}^{-1} \\
& \mathrm{FeS}_{2}+14 \mathrm{Fe}^{3+}+8 \mathrm{H}_{2} \mathrm{O} \rightarrow 15 \mathrm{Fe}^{2+}+2 \mathrm{SO}_{4}^{2-}+16 \mathrm{H}^{+} \\
& \quad \Delta \mathrm{H}=11 \mathrm{~kJ} \mathrm{~mol}^{-1}
\end{aligned}
$$

where $\Delta \mathrm{H}$ is the enthalpy change.

Heterogeneity with respect to the spatial variability of primary mineral contents in the mine waste occurring during the mine waste construction or deposition (i.e., the pre-weathered mineralogical content) is a first element controlling the extension of ARD (Morin and Hutt 2000). Such variability can be a signature of the randomness of the nature, and it is usually associated with the formation of the soils and rocks owing to long-term geological processes. Mineralogical heterogeneity can occur at any scale of interest, from impurities (Savage et al. 2008) and overgrowth textures (Weisener and Weber 2010) on sulfide grains to the variability in average mineralogical content within kilograms of rocks, as evaluated during static or kinetic tests (Parbhakar-Fox and Lottermoser 2015). Heterogeneity in primary minerals is also observed at larger scales, from experimental to operational-scale (fullscale) mine waste sites (St-Arnault et al. 2020; Vriens et al. 2019). Since fine-grained materials are generally much more reactive than coarse grained materials (Strömberg and Banwart 1994), there is a strong connection between physical and geochemical heterogeneities that can have a key implication for the release and mobility of ARD in heterogeneous waste rocks. Heterogeneity associated with the distribution of secondary mineral contents (i.e., the post-weathered mineralogical content) is another important element controlling the extension of ARD (Servida et al. 2013; Wisotzky 1994). Al et al. (2000) concluded that "reactions with the secondary minerals, rather than the primary mineral substrate, probably represent the principal controls on trace-element distributions in the pore water". This conclusion seems supported by several other studies (e.g. Laurenzi et al. 2015; van der Sloot and van Zomeren 2012).

From a modeling perspective, embedding geochemical reactions in predictive heterogeneous waste rocks is computationally challenging. Early models embedded largely simplified geochemical systems compared to the multicomponent and strongly nonlinear reactions characterizing true geochemical systems. The TOUGH-AMD model (Lefebvre et al. 2001a, b) was developed and used to evaluate the role of fine-grained zones as capillary barriers impeding oxygen penetration across waste rocks dominated by diffusion and convective transport regimes. Their results indicated that the presence of such physical heterogeneities strongly limits the distribution of convective cells, reducing in turn the generation of ARD. However, the geochemical formulation in TOUGH-AMD is also limited to a few selected processes (Lefebvre et al. 2001a, b), particularly those generating sulfide leachate, without the possibility to consider, for instance the effects of mineral buffering or the formation of secondary minerals.

One of the first deterministic multicomponent reactive transport model on waste rocks was presented by Molson et al. (2005), who coupled HYDRUS-2D and POLYMIN model. Their study provided important evidences of the role of heterogeneity, included for instance the impact of preferential flow for the assessment of ARD. Molson et al. (2005) coupled unsaturated flow models with a reactive model that accounted for the most important elements controlling the formation of ARD from the weathering of sulfide-rich waste rocks, including oxygen supply and the presence of buffering minerals, such as calcite. Heterogeneity was imposed to these models by layering the textural properties of the waste rocks, and in addition by inclining these layers. The results highlight that heterogeneity has a key influence on the overall emergence of ARD. Molson et al. (2005) concluded that "it is necessary to understand the moisture distribution and flow system together with the grain size distribution, oxygen concentrations, geochemistry and waste rock mineralogy". For example, low-pH water which accumulates within stagnant flow zones will not contribute to ARD loading. 


\section{Quantifying the uncertainty: stochastic modeling}

When dealing with geological media, an individual model outcome cannot be considered as the valid result for decision making purposes. Indeed, the lack of exhaustive knowledge of the subsurface often renders the mapping of properties and/or the parameterization adopted to describe a variable uncertain and prone to error, leading to both epistemic and aleatory uncertainties (Christakos 2000; Tartakovsky 2013). For predictive purposes, stochastic modeling provides a more versatile manner to deal with such uncertainty. In stochastic modeling, a probabilistic range of possible model results is provided instead of a single model output resulting from deterministic modeling. This enables the modeler to estimate not only the expected value of the distribution but also, and more importantly, the range of uncertainty surrounding the expected value. Among the multiple approaches for stochastic modeling in subsurface hydrology, the most popular is likely MonteCarlo (MC) based modeling embedding geostatistical descriptions of one or more random spatial properties of the aquifers. In MC modeling, instead of recreating only one possible version of the reality, a set of equally plausible "worlds" is reproduced. Real-life sparsely distributed measurements and observations can be fully incorporated in (or "honored by") the models. Conditional or unconditional simulations are described through probability density functions and other relationships, such as spatial correlations, that allow for a statistical mapping of the model outputs. Chief among these properties is the variability of $K$ used in stochastic modeling since the 1970s (Freeze 1975). However, any variable can be virtually chosen as random spatial functions. For instance, waste rocks are partially water-saturated deposits, hence, in the stochastic analyses of such unsaturated systems, the full range of parameters characterizing the characteristic unsaturated curves, such as the van Genuchten (1980) model parameters, can be treated as random spatial functions (e.g. Russo 2012).

In the context of ARD modeling in waste rocks, limited stochastic models have been presented in the literature. One reason is that the variability of the model parameters is not only limited to physical properties of the waste rocks (e.g. the hydraulic parameters) but also on geochemical parameters (e.g. Gerke et al. 1998). This issue poses additional challenges in the numerical solution of the fully coupled partial differential equations within MC context. However, stochastic reactive transport modeling remains particularly useful for predictive purposes under uncertainty. This type of modeling is appealing for risk-based analysis, given that a result can be expressed using a range of possible values, with a quantitative description of the likelihood of ARD (Pedretti et al. 2017a).

The following sections provide a summary of the stochastic analyses that have been presented tackling ARD from mining waste deposits. A summary of the main stochastic reactive transport models and related parameters can be found in Table 1. Note that not all the analyses presented below were developed with the explicit goal of quantifying the uncertainty in ARD. Yet, these analyses considered the randomness of model inputs and outputs, and therefore are more appropriate to uncertainty analysis than the modeling studies presented in Sect. 2 (even though in some cases the codes or algorithms were the same).

\subsection{Approaches based on Eulerian modeling}

Most stochastic analyses on heterogeneous multidimensional and multicomponent reactive transport models for the assessment of ARD from waste rocks have relied on Eulerian-based modeling. The main advantage of Eulerian models is that they can incorporate the full range of physical and geochemical processes occurring in waste rocks. The main drawback is that these models require high computational costs that may prevent their use for stochastic applications (particularly those involving many model solutions, such as in MC frameworks).

Gerke et al. (1998) presented one of the first-documented multidimensional multicomponent stochastic-based reactive transport models for the assessment of ARD from waste rocks. Their focus was on physical and chemical heterogeneity caused by mixing of soil materials that may have already been oxidized to different degrees during the deposition of the spoil pile. To this end, they generated a two-dimensional layered flow and reactive transport model where the generation of ARD occurred under diffusive gas transport conditions. According to Gerke et al. (1998), this assumption ignores geochemical reaction kinetics and the role of bacteria by assuming the oxidation rate at the mineral grain surface is fast compared to the oxygen diffusion rate. In order to account for the depositionally induced structure of the spoil pile, they considered the relative (unsaturated) permeability $K_{r}$, the unoxidized grain radius in the shrinking-core model $\left(r_{c}\right)$, and the fraction of sulfide mineral $\left(f_{s}\right)$ as spatially variable random fields. An unconditional geostatistical field (i.e. an "individual realization") was constructed using the Sequential Gaussian Simulations (SGSIM) module of GSLIB (Deutsch and Journel 1998), using an exponential autocorrelation approach. While SGSIM can create anisotropic correlated random spatial fields, Gerke et al. (1998) opted for spatial distribution of the fraction of sulfur to be more dependent on the properties of the geologic material than the deposition technique. Thus, they chose autocorrelation lengths 
Table 1 Summary of stochastic reactive transport modeling analyses presented since 1997. SGS $=$ Sequential Gaussian Simulations; SIS $=$ Sequential Indicator Simulation; MPS = Multiple Point Geostatistics. n.c. $=$ data not readily available from references. For the

\begin{tabular}{|c|c|c|c|c|}
\hline References & Approach / adopted codes & $\begin{array}{l}\text { Geostatistical } \\
\text { model } \\
\text { (Monte } \\
\text { Carlo?) }\end{array}$ & $\begin{array}{l}\text { Key stochastic } \\
\text { variables }\end{array}$ & Key parameters \\
\hline Eriksson et al. (1997) & Lagrangian model & $\begin{array}{l}\text { None } \\
(\mathrm{No})\end{array}$ & $\begin{array}{l}\text { Travel time }(t), \log - \\
\text { normally } \\
\text { distributed }\end{array}$ & 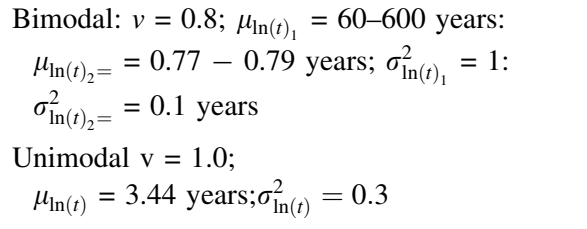 \\
\hline Gerke et al. (1998) & $\begin{array}{l}\text { SWMS_2D + MINTRAN } \\
\text { 2D vertical section }\end{array}$ & $\begin{array}{l}\text { SGS; } \\
\text { Exponential } \\
\text { correlation } \\
\text { (No) }\end{array}$ & $\begin{array}{l}\text { Relative } \\
\text { permeability } K_{r} \\
\text { unoxidized grain } \\
\text { radius in the } \\
\text { shrinking-core } \\
\text { model }\left(r_{c}\right) \\
\text { sulfide mineral } \\
\text { fraction }\left(f_{s}\right)\end{array}$ & $\begin{array}{l}\text { Two-layers structure } \\
K_{r}, r_{c}: \mu=\text { n.c.; } \sigma_{0}=0.01 . \sigma: \text { n.c. } \lambda=0.4-4 \mathrm{~m} \\
\quad \text { (upper layer,),0.1-10 m (lower layer) } \\
f_{s}: \mu=0.001 ; \sigma_{0}=0.1 ; \sigma: \text { non indicated } \lambda=4 \mathrm{~m} \\
\quad \text { (upper layer) and } 1.2 \mathrm{~m} \text { (lower layer) }\end{array}$ \\
\hline Fala et al. (2013) & $\begin{array}{l}\text { HYDRUS- } \\
2 \mathrm{D}+\text { POLYMIN } \\
2 \mathrm{D} \text { vertical section }\end{array}$ & $\begin{array}{l}\text { SGS; } \\
\text { Exponential } \\
\text { correlation } \\
\text { (No) }\end{array}$ & $\begin{array}{l}\text { Hydraulic } \\
\text { conductivity }(K) \\
\text { Pressure head }(\psi) \\
\text { Vol. water } \\
\text { content, }(\theta)\end{array}$ & $\begin{array}{l}\mathrm{K}: \mu=4.7 \times 10^{-3}-5.1 \times 10^{-5}\left(\mathrm{~ms}^{-1}\right) \\
\quad \sigma=1-1000 ; \lambda=5-100 \mathrm{~m} ; \\
\psi: \mu=n . c . ; \sigma=1-1000 ; \lambda=5-100 \mathrm{~m} \\
\theta: \mu=0.29-0.39 ; \sigma=0.1 ; \lambda=5-100 \mathrm{~m}\end{array}$ \\
\hline $\begin{array}{l}\text { Lahmira et al. } \\
(2017,2016)\end{array}$ & $\begin{array}{l}\text { TOUGH-AMD } \\
\text { 2D vertical Section }\end{array}$ & $\begin{array}{l}\text { None } \\
\text { (No) }\end{array}$ & $\begin{array}{l}\text { Permeability }(k) \\
\text { van Genuchten air- } \\
\text { entry pressure }(\alpha) \\
\text { and shape } \\
\text { parameters }(\mathrm{m})\end{array}$ & $\begin{array}{l}\mathrm{k}: \mu=5.0 \times 10^{-9}-5.0 \times 10^{-11}\left(\mathrm{~m}^{2}\right) ; \sigma=\text { n.c. } ; \\
\quad \lambda=\text { n.c } \\
\alpha: \mu=0.35-4.90\left(\mathrm{kPa}^{-1}\right) ; \sigma=\text { n.c.; } \lambda=\text { n.c }\end{array}$ \\
\hline $\begin{array}{l}\text { Pedretti et al. } \\
\quad(2016,2017 \mathrm{a}, \mathrm{b}, 2020)\end{array}$ & MATLAB + MIN3P & $\begin{array}{l}\text { SIS } \\
\text { (Yes) }\end{array}$ & $\begin{array}{l}\text { Calcite and pyrite } \\
\text { vol. fractions }(\varphi) \\
\text { Specific discharge } \\
\text { rates }(\mathrm{q})\end{array}$ & $\begin{array}{l}\varphi: \mu=0.05-0.25 \text { (calcite), } 0.05 \text { (pyrite) } \\
\sigma / \mu=0.6, \lambda=10 \mathrm{~m} \text { (parallel to tipping } \\
\text { phase) } 5 \mathrm{~m} \text { (transversal to tipping phases) } \\
q=\text { lognormal distribution with } \mu=10 \mathrm{~mm} / \mathrm{d} \\
\text { per streamtube amd variable } \sigma\end{array}$ \\
\hline
\end{tabular}

specific name of the variables, acronyms of models and specific information, we refer the reader to the text. Parameters: $\mu=$ mean; $\sigma_{0}=$ nugget, $\sigma=$ standard deviation, $\lambda=$ correlation length; $\mathrm{v}=$ proportion of matrix flow

$$
\begin{aligned}
& \mu_{\ln (t)_{2}=}=0.77-0.79 \text { years; } \sigma_{\ln (t)_{1}}^{2}=1: \\
& \sigma_{\ln (t)_{2}=}^{2}=0.1 \text { years } \\
& \text { Unimodal } \mathrm{v}=1.0 ;
\end{aligned}
$$$$
\text { Two-layers structure }
$$$$
r_{r}, r_{c}: \mu=\text { n.c.; } \sigma_{0}=0.01 . \sigma: \text { n.c. } \lambda=0.4-4 \mathrm{~m}
$$$$
\mu=0.001 ; \sigma_{0}=0.1 ; \sigma: \text { non indicated } \lambda=4 \mathrm{~m}
$$ 
The results by Fala et al. (2013) suggested that ARD is strongly sensitive to the selected material in the piles and the orientation and correlation lengths of the anisotropic autocorrelation model. For instance, in the layered case, the flow field is predominantly subvertical (due to the gravitydriven conditions imposed to the model), however $\lambda$ and the variance of the properties $\left(\sigma^{2}\right)$ generate local deviations which affect, for instance, the impact of preferential flow. The rates of sulfide mineral oxidation are influenced by the grain size, sulfide fraction and moisture content distribution. An important aspect discussed by Fala et al. (2013) is that the multiple realizations should be compared to find the general effects of heterogeneous properties on the expected behavior of the waste rocks. They finally indicated that the simulated models "can take many days", suggesting that "it may not be practical to conduct fully stochastic analyses (for most situations)"'. As discussed later, we contend that this may be the case today, however the increasing capacity of computational machines can generate a breakthrough also in the extended use of stochastic methods for ARD studies, bypassing the difficulties to computationally resolve MC simulations of nonisothermal multicomponent, multiphase, and multidimensional reactive transport of systems with complex geometries.

Lahmira et al. (2017) extended the model setup presented by Lefebvre et al. (2001a, b) to study the effects of a random variability in physical properties within the waste rocks on the resulting ARD. They kept an identical conceptual model and base model setup, which consists of a fine-grained layer at the top of the pile with a lateral inclined batter. In Lahmira et al. (2017), the authors compared three random spatial distributions of the heterogeneous materials. The realizations represent a mixed distribution without a specific correlation pattern, as no geostatistical model has been used to create the random spatial fields.

The results by Lahmira et al. (2017) confirmed that lowpermeability compacted layers strongly limit convection, as in the deterministic models. The presence of fine-grained material near the boundary of a pile can limit air entry while beneath the pile surface favors the internal condensation of water vapor and thus minimize water loss. Coarse materials on the other hand seem to promote preferential flow of gas and water vapor. Lahmira et al. (2017) indicated that secondary gas convection cells can exist in the pile because of heterogeneity. The initiation of such secondary cells requires a minimal degree of heterogeneity, which is closely related to the ratio of permeabilities between coarse and fine materials. Lahmira et al. (2017) pointed out that the presence of coarse-grained material in the pile does not necessarily lead to more convection and higher ARD production, as the magnitude of convection seems to be controlled more by the amount of fine-grained material and its distribution in the pile. Specifically, the authors conclude that the presence of fine and very fine materials that remain at high water saturations constitute barriers to gas flow.

\subsection{Approaches based on Lagrangian modeling}

Lagrangian, or particle-based, models are alternative options to Eulerian based models which are particularly appealing for stochastic reactive transport modeling. Compared to Eulerian based mechanistic models, in Lagrangian modeling the complexity of a fully-developed heterogeneous flow and reactive transport model is usually simplified, resulting in efficient computational time. Lagrangian models do not yet include the full range of nonlinear processes controlling the formation and fate of ARD in waste rocks, although research is very active and promising regarding the possible use of Lagrangian models for multicomponent reactive transport (Engdahl et al. 2019; Henri and Fernàndez-Garcia 2015; Lu et al. 2018; Schmidt et al. 2019). Engdahl et al. (2017) provides an example of application of a particle-based model analysis including most of ARD generating processes in a sulfide-rich mining environment.

Lagrangian models embed statistical distributions of selected parameters that enable reproducing the salient random nature of a variable of interest. As such, they become very useful for uncertainty analyses that require multiple realizations to be resolved in computationallyefficient times. A classic example is for instance the amount of mass or the concentration of solutes passing a control section over time, i.e. the BTC. This BTC can be a random output of a model that embeds a random distribution of key parameters controlling the uncertainty (e.g. $K$ ), while leaving the other parameters constant (Eriksson and Destouni 1997; Fiori et al. 2017; Pedretti and Bianchi 2018).

One of the first effective stochastic models for waste rocks was presented by Eriksson and Destouni (1997), who developed a stochastic dynamic modeling framework focused on the implication of flow heterogeneity on copper leaching through the Aitik waste rock heaps. The approach by Eriksson and Destouni (1997) was based on a probabilistic Lagrangian framework for reactive subsurface transport. Although the conceptual model is simplified compared to a real-case scenario, the Eriksson and Destouni (1997) model emphasizes the need to account for a distribution of possible model outcomes with a given range of uncertainty rather than a deterministic result. Their primary variable of interest was the water travel time, $t$, 
which was expressed by a bimodal probability density function (pdf), $f(t)$, of form:

$f(t)=v f_{1}(t)+(1-v) f_{2}(t)$

$f_{i}(t)=\frac{1}{\sqrt{ }\left(2 \pi \sigma_{t}^{2}\right)} \exp \left(-\frac{1}{2}\left(\frac{\ln (t)-\ln \left(t_{G}\right)}{\sigma_{t}^{2}}\right)\right) i=1,2$

where $v$ is the fraction of slow flow path in the system, i.e. the matrix flow $(1-v$ being the proportion of preferential flow paths), while $t_{G}$ and $\sigma_{t}^{2}$ are the mean and variance of the population of residences time, respectively for slow flow paths $(i=1)$ and the population of preferential flow paths $(i=2)$. The ensemble of values $t$ is then embedded into a 1-D analytical solution of the reactive transport, in which, $t$ becomes a scaling variable controlling the firstorder kinetics of copper dissolution rates. The model also considers the equilibrium precipitation of secondary copper minerals.

The results by Eriksson and Destouni (1997) showed that a stochastic selection of input parameters controlling preferential flow generates substantially different results than a deterministic selection of these parameters. The model by Eriksson and Destouni (1997) has inspired a number of subsequent model-based analyses of ARD in mining sites (e.g. Blackmore et al. 2018; Malmström et al. 2008; Pedretti et al. 2017a, 2020) and is considered a pioneering work in this field. The approach by Eriksson and Destouni (1997) has the main advantage of being computationally efficient, given that most of the key equations were linearized by the physically-based approximations and assumptions made by the authors. However, such simplification reduced the number of processes compared to a real site. Indeed, the model does not "predict" long-term copper leaching from the Aitik site. As acknowledged by the authors, this would have required a detailed geochemical model that had accounted for multiple processes, which cannot be treated analytically. Rather, the model showed that probabilistic Lagrangian models can serve to obtain a sensitivity to selected model variables, which help focusing field studies in waste rocks, such as tracer tests in the case of the assessment of preferential flow.

\section{3 "Hybrid" approaches}

Lagrangian approaches account for oversimplified geochemical systems to be predictive for waste rock systems, while Eulerian models are still too computationally demanding to perform a true stochastic analysis based on MC simulations. Although the capacity of computational machines is always evolving, as discussed later in the paper, nowadays alternative approaches must be sought if MC models are performed for routine applications, such as quick uncertainty analysis performed by practitioners, which may not have access to special computation platforms (e.g. supercomputers) or have more limited programming and modeling skills than advanced researchers.

In a series of recent papers, Pedretti et al. (2016, 2017a, b, 2020) presented and applied an efficient stochastic modeling framework able to account for the majority of mechanisms leading to ARD from waste rocks within a probabilistic context. The method is promising to obtain a quick estimation of the likelihood of ARD occurrence in mineralogically and physically heterogeneous context. The method includes ARD- and waste-rockspecific processes, such as rate-limited gas transport or multicomponent geochemical systems. This approach portrays a multidimensional system as discretized into a set of flow-paths, loosely described as "streamtubes". After splitting the system into $N$ "streamtubes", stochastic modeling was conducted considering each streamtube as a 1-D reactive transport problem, along which ARD forms from the interaction between gas, infiltrating and pre-existing pore water and primary and secondary waste rock minerals. The amount of streamtubes depends on the degree of flow heterogeneity, which is described via travel time pdfs, i.e. in the spirit of the Lagrangian approach by Eriksson and Destouni (1997). However, the solution of transport in each streamtube is achieved via Eulerian modeling. As such, the stochastic modeling framework by Pedretti et al. (2016, 2017a, b, 2020) can be seen as an "hybrid" modeling approach.

In Pedretti et al. (2020, 2017a, b, 2020) the multicomponent multiphase reactive transport code MIN3P (Mayer et al. 2002) was utilized with simple MATLAB-based scripting for input and output processing. Alternative solutions for the implementation of the geochemical solvers in the multipurpose reactive transport simulations and parallelization can be used for similar purposes. For instance, when adopting codes from the family of geochemical code PHREEQC (Parkhurst and Appelo 2013), two new modules, IPhreeqc (Charlton and Parkhurst 2011) and PhreeqcRM (Parkhurst and Wissmeier 2015) are specifically designed to access PHREEQC's reaction capabilities from any scripting languages. This facilitates a faster communication between the geochemical code and transport simulators without the need of reading/writing external files (Muniruzzaman et al. 2020; Muniruzzaman and Rolle 2016, 2019; Rolle et al. 2018; Sprocati et al. 2019).

The results from the framework proposed by Pedretti et al. $(2016,2017 \mathrm{a}, \mathrm{b}, 2020)$ are presented in the form of pdfs or cdfs of the ensemble of model outputs of target variables, as in any other stochastic analysis. These model outputs are derived from the mixed concentration of components forming the geochemical models and arriving 
at a specific control section (e.g. the bottom of the waste rock piles), where they mix over time using a flux-weighted formulation. So far, the approach has been successfully applied to estimate the effective neutralizing capacity of heterogeneous waste rock piles. Results are expressed as pdfs of the concentration of a solute component (e.g. $\mathrm{SO}_{4}$ ) or the $\mathrm{pH}$. For instance, the expected $\mathrm{pH}$ after 100 years from the starting of waste rocks weathering is obtained, along with the degree of uncertainty (e.g. the $95 \%$ confidence interval).

The key advantage of the approach by Pedretti et al. $(2016,2017 \mathrm{a}, \mathrm{b}, 2020)$ is that it is extremely efficient from a computational perspective, being easily parallelizable. A MC analyses composed by 100 realizations, each one composed by 100 streamtubes, correspond to 10,000 individual 1-D multicomponent reactive. For instance, tested simulations in Pedretti et al. (2016, 2017a, b, 2020) ran overnight to complete a MC analysis on a workstation based on 4-cores Intel ${ }^{\circledR}$ Xeon ${ }^{\circledR}$ E-2124G $3.40 \mathrm{GHz}$. The main drawback is that the discretization into 1-D models is a necessary simplification to avoid the problems linked to multidimensional Eulerian models. The limitations of this simplification are described in the cited literature.

\section{A perspective on the evolution of the discipline}

For several decades, research and applications in mining and hydrogeology have been evolved separately. Nowadays, thanks to multiple projects sponsored by mining companies looking at integrating research and mining practices, international conferences and workshops, scholars and practitioners seem to converge on the idea that a better understanding and more reliable prediction of acid rock drainage (ARD) requires multidisciplinary approaches able to bridge cutting-edge scientific advances with practical needs. Mathematical modeling has been part of this evolution and mechanistic models can now embed almost all known partial differential equations controlling the main physical and geochemical processes generating ARD in waste rocks (Amos et al. 2015).

The increasing capability of workstations and supercomputers is however the key aspect to define the perspectives regarding the evolution of the discipline in the incoming future. The following is the authors' perspective regarding possible topics that will be progressively addressed by researchers and practitioners in the following years.

\subsection{Communicate the need of stochastic modeling beyond the academic boundaries}

When dealing with waste rocks modeling, it must be understood by practitioners that the result from any model will be uncertain. If deterministic analysis is used, that results will be certainly wrong and possibly too unreliable to make a decision out of it. The first reason is that waste rocks are complex environments in which physical, chemical, and biological processes are interrelated (Fig. 1) and the spatial and temporal variability of the properties controlling these processes are often insufficiently characterized to the scales which are relevant to make use of deterministic modeling approaches. The second reason is that, even when the full range of virtually-available spatially-distributed heterogeneous properties of a waste rock were known, the modeler could not incorporate this knowledge into a code, as it would result in too high computational burden.

Stochastic modeling has been proved to assist modeler when dealing with these difficulties, such as through moment-based analysis to cope with data limitations or via parameter upscaling. Stochastic models generate probabilistic results, such that decision makers can decide, for instance, whether a waste rock deposit will generate some polluted drainage, how much it will cost to remediate to such contamination or how to ensure that any drainage is properly controlled. All these decisions will be made with a known degree of uncertainty.

Unfortunately, stochastic hydrogeological modeling struggles to be fully accepted beyond the academic boundaries (Bode et al. 2018; Freeze 2004; Renard 2007; Sanchez-Vila and Fernàndez-Garcia 2016), and convincing mining practitioners is not an easy task. In the words of Sanchez-Vila and Fernàndez-Garcia (2016), who rephrased Renard (2007), modelers must understand that "deterministic models do not represent reality at all. The reason is the combination of unsampled natural heterogeneity and scenario uncertainty. Only stochastic models have a chance of providing the answers needed for proper groundwater management efforts."

While recent works (Fala et al. 2013; Lahmira et al. 2017; Pedretti et al. 2017a) suggest that it is already possible to use stochastic reactive transport modeling for predictive purposes in waste rocks, the true "revolution" is expected to occur when modelers in consultant agencies will be convinced by researchers and, more importantly, will have easy access to parallel computing for reactive transport modeling. Parallel computing has bloomed years ago (Steefel et al. 2014), and several codes have been adapted since then (e.g. Parkhurst and Wissmeier 2015; Su et al. 2017). Monte Carlo modeling on multidimensional 
multicomponent reactive transport models for waste rocks will be possible to generate stochastic scenarios of multiple realizations, which will provide expected behavior of the waste rocks along with quantified degree of uncertainty. For instance, this would help by-passing the simplifications of the approach proposed by Pedretti et al. (2016, 2017a, b, 2020).

\subsection{Pore-scale analyses}

ARD processes are controlled by microscopic phenomena (Pantelis and Ritchie 1992), while models are usually performed at much larger scales that lumps together multiple reactive sites. This is one of the reasons leading to the well-known scale dependence in reaction rates and a major debated issue in waste rocks studies (Amos et al. 2015).

We contend that in the next years the emerging characterization of modeling of flow and reactive transport heterogeneities at the pore scale (Blunt et al. 2013) will be a key focus to reduce uncertainty in waste rock modeling (and ARD modeling in general). One reason is the development and diffusion of modern machines for pico- and nano-scale imaging methods, in particular X-ray micro tomography (Sayab et al. 2015) and similar methods. These techniques have now allowed acquisition of three-dimensional reconstructions from a series of two-dimensional projections taken at different angles. Another major breakthrough in this discipline has been the increased availability of high resolution experimental investigations at the pore-scale, such as microfluidic experiments (de Anna et al. 2014; Zhang et al. 2010), or at the Darcy scale including spatially resolved measurements (Muniruzzaman et al. 2014; Muniruzzaman and Rolle 2015, 2017; Rolle et al. 2013).

Enhanced capability to resolve such small-scale physicochemical processes will lead to significant development not only in establishing process understanding but also in effective upscaling the effects of ARD mechanisms during large-scale transport. At the same time, the increasing capability of computational methods to resolve partial differential equations, such as the Stokes equation, on high-resolution grids has allowed a prompt blooming of studies focusing, for instance, on the role of local dispersion, reactive transport, or mineral-solution interactions at the scale of the pore (Yoon et al. 2015), thus circumventing the problems of scales in hydrogeological modeling.

\subsection{Connectivity and spatial order}

Transport in heterogeneous media is very sensitive to the degree of connectivity of the clusters (Bianchi et al. 2011; Bianchi and Pedretti 2017, 2018; Knudby et al. 2006; Molinari et al. 2015; Renard and Allard 2013) and to the spatial ordering of the structures forming a geological medium. Connectivity, clustering and spatial ordering can be measured in multiple manners, e.g. through the analysis of geological entropy (Bianchi and Pedretti 2018, 2017; Pedretti 2020; Pedretti and Bianchi 2019; Ye et al. 2018). However, connectivity is not yet an established aspect for waste rock modeling. It is expected that this will become an important issue for future development in the area, particularly related to the impact of preferential flow and channeled transport in the waste rocks. One of the most recent works in this sense is Appels et al. (2018). Although they did not implement a reactive transport model analysis as in the above-mentioned contributions, their work was one of the first to adopt multiple point geostatistics (MPS), which allow to incorporate connectivity of textural properties and associated hydraulic and transport properties (e.g. $K$ clusters). In particular, the connectivity of extreme patterns is honored by MPS compared to, for instance, Sequential Gaussian Simulations, where extremes tend to be smoothed out and underestimate the impact of connected features on transport (e.g. Renard and Allard 2013).

\subsection{Biologically-controlled kinetics}

Microbially-controlled reactions have a dominant role to control the scales of ARD in waste rocks. The spatial variability of biologically-related parameters can be as important as the variability of physical and geochemical parameters. Yet, little evidences of waste rock models embedding heterogeneous distribution of parameters directly related to microbial activity and their impact on ARD were found while reviewing the literature for this paper. The most adopted approach so far seems to be the use of effective kinetic rates that lump together both the reaction rates associated to geochemical properties of waste rocks and the effects of microbially-induced reactions.

Models nonetheless exist to include explicitly the spatial effects of microbially-induced reactions, for instance as shown by Casas et al. (1998). Modeling the spatio-temporal variability of microbial colonies using stochastic approaches could enable reproducing the uncertainty associated to the scarce knowledge of the biologically controlled kinetics of ARD generation. A key starting point could be the definition of model zonations based on geostatistical distribution of "acidic microenvironments" (Dockrey et al. 2014) at sulfide mineral surfaces in order to catalyze the sulfide oxidation processes even under circumneutral $\mathrm{pH}$ conditions (Southam and Beveridge 1993). Such acidic microenvironments are thought to be sustained by the simultaneous occurrence of ferric (oxy)hydroxide and/or (oxy)hydroxysulfate precipitation, which allows an isolation of these microenvironments from the bulk pH-neutral 
pore water solution within the close proximity of the sulfide surface (Mielke et al. 2018; Pace et al. 2018).

A second approach could be based on the simulation of the spatial distribution of the habitats for these colonies. For instance, the porous layer of the secondary $\mathrm{Fe}^{3+}$ phases (e.g., K-jarosite, schwartmannite) essentially provides important habitats for developing microbial colonies and biofilms of acidophilic bacteria under bulk non-acidic conditions (Dockrey et al. 2014). Consequently, in these so-called acidic microenvironments, $\mathrm{Fe}^{3+}$ solubility is increased, sulfide weathering is locally enhanced, and the $\mathrm{pH}$ limiting growth condition of acidophilic species is overcome (Dockrey et al. 2014). Additionally, these bacterial species can deposit extracellular polymeric substances (EPS), which are also known to complex with $\mathrm{Fe}^{3+}$ and subsequently enhance sulfide dissolution kinetics by making it available for sulfide oxidation reactions (Sand et al. 1995).

Acknowledgements We thank two anonymous for their helpful comments on the early draft of the manuscript. We are grateful to Roger Beckie for his initial comments and useful suggestions about the structure and content of this paper. MM has been supported by internal funding for research and development (TUMMELI project) at the Geological Survey of Finland, European Regional Development Fund (KaiHaMe and Kaivasu projects). The results here presented have been developed in the frame of the MIUR Project "Dipartimenti di Eccellenza 2017-Le Geoscienze per la società: risorse e loro evoluzione".

Funding Open access funding provided by Università degli Studi di Milano within the CRUI-CARE Agreement.

\section{Compliance with ethical standards}

Conflicts of interest The authors declare that there is no conflict of interest regarding the publication of this paper.

Open Access This article is licensed under a Creative Commons Attribution 4.0 International License, which permits use, sharing, adaptation, distribution and reproduction in any medium or format, as long as you give appropriate credit to the original author(s) and the source, provide a link to the Creative Commons licence, and indicate if changes were made. The images or other third party material in this article are included in the article's Creative Commons licence, unless indicated otherwise in a credit line to the material. If material is not included in the article's Creative Commons licence and your intended use is not permitted by statutory regulation or exceeds the permitted use, you will need to obtain permission directly from the copyright holder. To view a copy of this licence, visit http://creativecommons. org/licenses/by/4.0/.

\section{References}

Akcil A, Koldas S (2006) Acid mine drainage (AMD): causes, treatment and case studies. Improving environmental, economic and ethical performance in the mining industry. Part 2 life cycle and process analysis and technical issues. J Clean Prod 14:1139-1145. https://doi.org/10.1016/j.jclepro.2004.09.006

Al TA, Martin CJ, Blowes DW (2000) Carbonate-mineral/water interactions in sulfide-rich mine tailings. Geochim Cosmochim Acta 64:3933-3948. https://doi.org/10.1016/S00167037(00)00483-X

Allison JD, Brown DS, Novo-Gradac KJ (1991) MINTEQA2/ PRODEFA2, a geochemical assessment model for environmental systems: version 3.0 user's manual. Research Laboratory, Office of Research and Development, US

Amos RT, Blowes DW, Bailey BL, Sego DC, Smith L, Ritchie AIM (2015) Waste-rock hydrogeology and geochemistry. Environmental geochemistry of modern mining. Appl Geochem 57:140-156. https://doi.org/10.1016/j.apgeochem.2014.06.020

Appels WM, Ireson AM, Barbour SL (2018) Impact of bimodal textural heterogeneity and connectivity on flow and transport through unsaturated mine waste rock. Adv Water Resour 112:254-265. https://doi.org/10.1016/j.advwatres.2017.12.008

Bailey BL, Smith LJD, Blowes DW, Ptacek CJ, Smith L, Sego DC (2013) The diavik waste rock project: persistence of contaminants from blasting agents in waste rock effluent. Appl Geochem 36:256-270. https://doi.org/10.1016/j.apgeochem.2012.04.008

Baker BJ, Banfield JF (2003) Microbial communities in acid mine drainage. FEMS Microbiol Ecol 44:139-152. https://doi.org/10. 1016/S0168-6496(03)00028-X

Battistel M, Muniruzzaman M, Onses F, Lee J, Rolle M (2019) Reactive fronts in chemically heterogeneous porous media: experimental and modeling investigation of pyrite oxidation. Appl Geochem 100:77-89. https://doi.org/10.1016/j.apgeochem. 2018.10.026

Betrie GD, Sadiq R, Nichol C, Morin KA, Tesfamariam S (2016) Environmental risk assessment of acid rock drainage under uncertainty: the probability bounds and PHREEQC approach. J Hazard Mater 301:187-196. https://doi.org/10.1016/j.jhazmat. 2015.07.022

Beven K, Germann P (2013) Macropores and water flow in soils revisited. Water Resour Res 49:3071-3092. https://doi.org/10. 1002/wrcr.20156

Bianchi M, Pedretti D (2018) An entrogram-based approach to describe spatial heterogeneity with applications to solute transport in porous media. Water Resour Res 54:4432-4448. https:// doi.org/10.1029/2018WR022827

Bianchi M, Pedretti D (2017) Geological entropy and solute transport in heterogeneous porous media. Water Resour Res 53:4691-4708. https://doi.org/10.1002/2016WR020195

Bianchi M, Zheng CM, Wilson C, Tick GR, Liu G, Gorelick S (2011) Spatial connectivity in a highly heterogeneous aquifer: From cores to preferential flow paths. Water Resour Res 47:W05524. https://doi.org/10.1029/2009WR008966

Bigham JM, Nordstrom DK (2000) Iron and aluminum hydroxysulfates from acid sulfate waters. Rev Miner Geochem 40:351-403. https://doi.org/10.2138/rmg.2000.40.7

Binning PJ, Postma D, Russell TF, Wesselingh JA, Boulin PF (2007) Advective and diffusive contributions to reactive gas transport during pyrite oxidation in the unsaturated zone. Water Resour Res 43:W02414. https://doi.org/10.1029/2005WR004474

Blackmore S, Pedretti D, Mayer KU, Smith L, Beckie RD (2018) Evaluation of single- and dual-porosity models for reproducing the release of external and internal tracers from heterogeneous waste-rock piles. J Contam Hydrol 214:65-74. https://doi.org/10. 1016/j.jconhyd.2018.05.007

Blackmore S, Smith L, Mayer KU, Beckie RD (2014) Comparison of unsaturated flow and solute transport through waste rock at two experimental scales using temporal moments and numerical modeling. J Contam Hydrol 171:49-65. https://doi.org/10.1016/ j.jconhyd.2014.10.009 
Blowes DW, Ptacek CJ, Jambor JL, Weisener CG (2003) The geochemistry of acid mine drainage. Treatise on geochemistry. Elsevier, Amesterdam, pp 149-204

Blowes DW, Ptacek CJ, Jambor JL, Weisener CG, Paktunc D, Gould WD, Johnson DB (2014) 11.5-The geochemistry of acid mine drainage. In: Holland HD, Turekian KK (eds) Treatise on geochemistry, 2nd edn. Elsevier, Oxford, pp 131-190. https:// doi.org/10.1016/B978-0-08-095975-7.00905-0

Blunt MJ, Bijeljic B, Dong H, Gharbi O, Iglauer S, Mostaghimi P, Paluszny A, Pentland C (2013) Pore-scale imaging and modelling. Adv Water Resour 51:197-216. https://doi.org/10.1016/j. advwatres.2012.03.003

Bode F, Ferré T, Zigelli N, Emmert M, Nowak W (2018) Reconnecting stochastic methods with hydrogeological applications: a utilitarian uncertainty analysis and risk assessment approach for the design of optimal monitoring networks. Water Resour Res 54:2270-2287. https://doi.org/10.1002/ 2017WR020919

Casas J, Vargas T, Martínez J, Moreno L (1998) Bioleaching model of a copper-sulfide ore bed in heap and dump configurations. Metall Mater Trans B 29:899-909. https://doi.org/10.1007/ s11663-998-0149-0

Charlton SR, Parkhurst DL (2011) Modules based on the geochemical model PHREEQC for use in scripting and programming languages. Comput Geosci 37:1653-1663

Christakos G (2000) Modern spatiotemporal geostatistics. Oxford University Press, New York

Christenson S (1995) Contamination of wells completed in the Roubidoux aquifer by abandoned zinc and lead mines, Ottawa county, Oklahoma. Water Resour Investig Rep. 95-4150

da Silva JC, do Amaral Vargas E, Sracek O (2009) Modeling multiphase reactive transport in a waste rock pile with convective oxygen supply. Vadose Zone J 8:1038-1050. https://doi.org/ 10.2136/vzj2008.0156

Davis GB, Doherty G, Ritchie AIM (1986) A model of oxidation in pyritic mine wastes: part 2: comparison of numerical and approximate solutions. Appl Math Model 10:323-329. https:// doi.org/10.1016/0307-904X(86)90091-0

Davis GB, Ritchie AIM (1987) A model of oxidation in pyritic mine wastes: part 3: import of particle size distribution. Appl Math Model 11:417-422. https://doi.org/10.1016/0307904X(87)90166-1

Davis GB, Ritchie AIM (1986) A model of oxidation in pyritic mine wastes: part 1 equations and approximate solution. Appl Math Model 10:314-322. https://doi.org/10.1016/0307904X(86)90090-9

Day SJ (1994) Evaluation of acid generating rock andacid consuming rock mixing to prevent acid rock drainage. In: International land reclamation and mine drainage conference and the third international conference on the abatement of acidic drainage. Pittsburgh, PA

de Anna P, Jimenez-Martinez J, Tabuteau H, Turuban R, Le Borgne T, Derrien M, Méheust Y (2014) Mixing and reaction kinetics in porous media: an experimental pore scale quantification. Environ Sci Technol 48:508-516. https://doi.org/10.1021/es403105b

Deutsch C, Journel A (1998) GSLIB: geostatistical software library and user's guide. Oxford University Press, New York, p 340

Dockrey J, Lindsay M, Mayer K, Beckie R, Norlund K, Warren L, Southam G (2014) Acidic microenvironments in waste rock characterized by neutral drainage: bacteria-mineral interactions at sulfide surfaces. Minerals 4:170-190. https://doi.org/10.3390/ $\min 4010170$

Dold B (2017) Acid rock drainage prediction: a critical review. J Geochem Explor 172:120-132. https://doi.org/10.1016/j.gex plo.2016.09.014
Engdahl NB, Benson DA, Bolster D (2017) Lagrangian simulation of mixing and reactions in complex geochemical systems. Water Resour Res 53:3513-3522. https://doi.org/10.1002/2017WR020362

Engdahl NB, Schmidt MJ, Benson DA (2019) Accelerating and parallelizing lagrangian simulations of mixing-limited reactive transport. Water Resour Res 55:3556-3566

EPA (1994) Technical document: acid mine drainage prediction. EPA 530-R-94-036 NTIS PB94-201829

Eriksson N, Destouni G (1997) Combined effects of dissolution kinetics, secondary mineral precipitation, and preferential flow on copper leaching from mining waste rock. Water Resour Res $33: 471-483$

Eriksson N, Gupta A, Destouni G (1997) Comparative analysis of laboratory and field tracer tests for investigating preferential flow and transport in mining waste rock. J Hydrol 194:143-163. https://doi.org/10.1016/S0022-1694(96)03209-X

European Commission (2009) Reference document on best available techniques for management of tailings and waste-rock in mining activities

Evangelou (Bill) VP, Zhang YL (1995) A review: pyrite oxidation mechanisms and acid mine drainage prevention. Crit Rev Environ Sci Technol 25:141-199. https://doi.org/10.1080/ 10643389509388477

Fala O, Molson J, Aubertin M, Bussière B (2005) Numerical Modelling of Flow and Capillary Barrier Effects in Unsaturated Waste Rock Piles. Mine Water Environ. 24:172-185. https://doi. org/10.1007/s10230-005-0093-z

Fala O, Molson J, Aubertin M, Dawood I, Bussière B, Chapuis RP (2013) A numerical modelling approach to assess long-term unsaturated flow and geochemical transport in a waste rock pile. Int J Min Reclam Environ 27:38-55. https://doi.org/10.1080/ 17480930.2011.644473

Fiori A, Zarlenga A, Jankovic I, Dagan G (2017) Solute transport in aquifers: the comeback of the advection dispersion equation and the first order approximation. Adv Water Resour 110:349-359. https://doi.org/10.1016/j.advwatres.2017.10.025

Freeze RA (2004) The role of stochastic hydrogeological modeling in real-world engineering applications. Stoch Environ Res Risk Assess 18:286-289

Freeze RA (1975) A stochastic-conceptual analysis of one-dimensional groundwater flow in nonuniform homogeneous media. Water Resour Res 11:725-741. https://doi.org/10.1029/ WR011i005p00725

Gerke HH, Molson JW, Frind EO (1998) Modelling the effect of chemical heterogeneity on acidification and solute leaching in overburden mine spoils. J Hydrol 209:166-185

Gray NF (1997) Environmental impact and remediation of acid mine drainage: a management problem. Environ Geol 30:62-71. https://doi.org/10.1007/s002540050133

Guadagnini A, Tartakovsky DM (2010) Uncertainty quantification in modeling flow and transport in porous media. Stoch Environ Res Risk Assess 24:953-954. https://doi.org/10.1007/s00477-0100396-x

Harries JR, Ritchie AIM (1981) The use of temperature profiles to estimate the pyritic oxidation rate in a waste rock dump from an opencut mine. Water Air Soil Pollut 15:405-423. https://doi.org/ 10.1007/BF00279423

Hendry MJ, Wassenaar LI, Barbour SL, Schabert MS, Birkham TK, Fedec T, Schmeling EE (2018) Assessing the fate of explosives derived nitrate in mine waste rock dumps using the stable isotopes of oxygen and nitrogen. Sci Total Environ 640-641:127-137. https://doi.org/10.1016/j.scitotenv.2018.05. 275

Henri CV, Fernàndez-Garcia D (2015) A random walk solution for modeling solute transport with network reactions and multi-rate mass transfer in heterogeneous systems: Impact of biofilms. Adv 
Water Resour 86:119-132. https://doi.org/10.1016/j.advwatres. 2015.09.028

INAP-GARD (2014) GARD (Global Acid Rock Drainage) Guide The international network for acid prevention (INAP). URL: https:// www.gardguide.com/

Johnson DB, Hallberg KB (2005) Acid mine drainage remediation options: a review. Bioremediation of Acid Mine Drainage: The Wheal Jane Mine Wetlands Project. Sci Total Environ 338:3-14. https://doi.org/10.1016/j.scitotenv.2004.09.002

Knudby C, Carrera J, Bumgardner JD, Fogg GE (2006) Binary upscaling: the role of connectivity and a new formula. Adv Water Resour 29:590-604. https://doi.org/10.1016/j.advwatres. 2005.07.002

Lahmira B, Lefebvre R, Aubertin M, Bussière B (2017) Effect of material variability and compacted layers on transfer processes in heterogeneous waste rock piles. J Contam Hydrol 204:66-78. https://doi.org/10.1016/j.jconhyd.2017.07.004

Lahmira B, Lefebvre R, Aubertin M, Bussière B (2016) Effect of heterogeneity and anisotropy related to the construction method on transfer processes in waste rock piles. J Contam Hydrol 184:35-49. https://doi.org/10.1016/j.jconhyd.2015.12.002

Laurenzi L, Mayer KU, Beckie R (2015) A Metal Attenuation Study on Waste Rock Collected from the East Dump, Antamina Mine, Peru: A Combined Mineralogical and Geochemical Approach. Proc 10th Int Conf Acid Rock Drain IMWA Annu Conf. Santiago, Chile, Chile 11

Lefebvre R, Hockley D, Smolensky J, Gelinas P (2001a) Multiphase transfer processes in waste rock piles producing acid mine drainage 1: conceptual model and system characterization. J. Contam, Hydrol, p 28

Lefebvre R, Hockley D, Smolensky J, Lamontagne A (2001b) Multiphase transfer processes in waste rock piles producing acid mine drainage: 2. Applications of numerical simulation. J Contam Hydrol 52:165-186. https://doi.org/10.1016/S01697722(01)00157-7

Lichtner PC, Tartakovsky DM (2003) Stochastic analysis of effective rate constant for heterogeneous reactions. Stoch Environ Res Risk Assess SERRA 17:419-429. https://doi.org/10.1007/ s00477-003-0163-3

Lottermoser B (2010) Mine wastes. Springer-Verlag, Berlin Heidelberg

Lu B, Zhang Y, Sun H, Zheng C (2018) Lagrangian simulation of multi-step and rate-limited chemical reactions in multi-dimensional porous media. Water Sci Eng 11:101-113. https://doi.org/ 10.1016/j.wse.2018.07.006

Ma L, Huang C, Liu Z-S, Morin KA, Aziz M, Meints C (2019) Prediction of acid rock drainage in waste rock piles Part 1: water film model for geochemical reactions and application to a fullscale case study. J Contam Hydrol 220:98-107. https://doi.org/ 10.1016/j.jconhyd.2018.11.012

Mahmood FN, Barbour SL, Kennedy C, Hendry MJ (2017) Nitrate release from waste rock dumps in the Elk Valley, British Columbia. Canada Sci Total Environ 605:915-928. https://doi. org/10.1016/j.scitotenv.2017.05.253

Malmström ME, Berglund S, Jarsjö J (2008) Combined effects of spatially variable flow and mineralogy on the attenuation of acid mine drainage in groundwater. Appl Geochem 23:1419-1436. https://doi.org/10.1016/j.apgeochem.2007.12.029

Mayer KU, Alt-Epping P, Jacques D, Arora B, Steefel CI (2015) Benchmark problems for reactive transport modeling of the generation and attenuation of acid rock drainage. Comput Geosci 19:599-611. https://doi.org/10.1007/s10596-015-9476-9

Mayer KU, Frind EO, Blowes DW (2002) Multicomponent reactive transport modeling in variably saturated porous media using a generalized formulation for kinetically controlled reactions: reactive transport modeling in variably saturated media. Water Resour Res 38:13-21. https://doi.org/10.1029/2001WR000862

MEND (1998) Risk Assessment and Management. Summary notes. 5th Annual BC Mem-MEND 2000 Metal Leaching \& ARD Workshop. Vancouver, BC,9-10 Dec

Mielke RE, Pace DL, Porter T, Southam G (2018) A critical stage in the formation of acid mine drainage: Colonization of pyrite by Acidithiobacillus ferrooxidans under $\mathrm{pH}$-neutral conditions. Geobiology 1:81-90. https://doi.org/10.1046/j.1472-4669.2003. 00005.x

Molinari A, Pedretti D, Fallico C (2015) Analysis of convergent flow tracer tests in a heterogeneous sandy box with connected gravel channels. Water Resour Res 51:5640-5657. https://doi.org/10. 1002/2014WR016216

Molson JW, Fala O, Aubertin M, Bussière B (2005) Numerical simulations of pyrite oxidation and acid mine drainage in unsaturated waste rock piles. J Contam Hydrol 78:343-371. https://doi.org/10.1016/j.jconhyd.2005.06.005

Molson JW, Frind EO, Aubertin M, Blowes D (2004) POLYMIN: a reactive mass transport and sulphide oxidation model. User Guide Ecole Polytech, Montr

Morin KA, Hutt NM (2008) Field study of unavailable neutralization potential in acidic rock. Unpublished web document

Morin KA, Hutt NM (2000) Discrete-zone mixing of net-acidneutralizing and net-acid-generating rock: avoiding the argument over appropriate ratios. Presented at the proceedings from the fifth international conference on acid rock drainage

Muniruzzaman M, Haberer CM, Grathwohl P, Rolle M (2014) Multicomponent ionic dispersion during transport of electrolytes in heterogeneous porous media: experiments and model-based interpretation. Geochim Cosmochim Acta 141:656-669. https:// doi.org/10.1016/j.gca.2014.06.020

Muniruzzaman M, Karlsson T, Ahmadi N, Rolle M (2020) Multiphase and multicomponent simulation of acid mine drainage in unsaturated mine waste: modeling approach, benchmarks and application examples. Appl Geochem 120:104677. https://doi. org/10.1016/j.apgeochem.2020.104677

Muniruzzaman M, Kauppila PM, Karlsson T (2018) Water quality prediction of mining waste facilities based on predictive models. Geol Surv Finl Open File Res Rep 16:67

Muniruzzaman M, Rolle M (2019) Multicomponent Ionic transport modeling in physically and electrostatically heterogeneous porous media with phreeqcrm coupling for geochemical reactions. Water Resour Res 55:11121-11143. https://doi.org/10. 1029/2019WR026373

Muniruzzaman M, Rolle M (2017) Experimental investigation of the impact of compound-specific dispersion and electrostatic interactions on transient transport and solute breakthrough. Water Resour Res 53:1189-1209. https://doi.org/10.1002/ 2016WR019727

Muniruzzaman M, Rolle M (2016) Modeling multicomponent ionic transport in groundwater with IPhreeqc coupling: electrostatic interactions and geochemical reactions in homogeneous and heterogeneous domains. Adv Water Resour 98:1-15. https://doi. org/10.1016/j.advwatres.2016.10.013

Muniruzzaman M, Rolle M (2015) Impact of multicomponent ionic transport on $\mathrm{pH}$ fronts propagation in saturated porous media. Water Resour Res 51:6739-6755. https://doi.org/10.1002/ 2015WR017134

Murr LE (1979) Observations of solution transport, permeability, and leaching reactions in large, controlled, copper-bearing waste bodies. Hydrometallurgy 5:67-93. https://doi.org/10.1016/0304386X(79)90028-8

Neuberger JS, Hu SC, Drake KD, Jim R (2009) Potential health impacts of heavy-metal exposure at the tar creek superfund site, 
Ottawa county. Oklahoma Environ Geochem Health 31:47-59. https://doi.org/10.1007/s10653-008-9154-0

Neuner M, Smith L, Blowes DW, Sego DC, Smith LJD, Fretz N, Gupton M (2013) The Diavik waste rock project: water flow through mine waste rock in a permafrost terrain. Appl Geochem 36:222-233. https://doi.org/10.1016/j.apgeochem.2012.03.011

Newman LL, Herasymuik G, Barbour LS, Fredlund DG, Smith T (1997) The hydrogeology of waste rock dumps and a mechanism for unsaturated preferential flow. Proceedings of fourth international conference on acid rock drainage, ICARD, p 551-566

Nichol C, Smith L, Beckie R (2005) Field-scale experiments of unsaturated flow and solute transport in a heterogeneous porous medium. Water Resour Res 41:W05018. https://doi.org/10.1029/ 2004WR003035

Nordstrom DK, Alpers CN (1999) Geochemistry of acid mine waters. Rev Econ Geol 6:133-160

Nordstrom DK, Blowes DW, Ptacek CJ (2015) Hydrogeochemistry and microbiology of mine drainage: an update. Appl. geochem environmental geochemistry of modern mining. Appl. Geochem 57:3-16. https://doi.org/10.1016/j.apgeochem.2015.02.008

Nordstrom DK, Southam G (1997) Geomicrobiology of sulfide mineral oxidation. Rev Mineral Geochem 35:361-390

Pace DL, Mielke RE, Southam G, Porter TL (2018) Scanning force microscopy studies of the colonization and growth of $\mathrm{A}$. ferrooxidans on the surface of pyrite minerals. Scanning 27:136-140. https://doi.org/10.1002/sca.4950270306

Pantelis G, Ritchie AIM (1992) Rate-limiting factors in dump leaching of pyritic ores. Appl Math Model 16:553-560. https:// doi.org/10.1016/0307-904X(92)90005-N

Papirio S, Villa-Gomez DK, Esposito G, Pirozzi F, Lens PNL (2013) Acid mine drainage treatment in fluidized-bed bioreactors by sulfatereducing bacteria: a critical review. Crit Rev Environ Sci Technol 43:2545-2580. https://doi.org/10.1080/10643389.2012.694328

Parbhakar-Fox A, Lottermoser BG (2015) A critical review of acid rock drainage prediction methods and practices. Miner Eng SI: Process Mineral 82:107-124. https://doi.org/10.1016/j.mineng. 2015.03.015

Parkhurst DL, Appelo CAJ (2013) Description of input and examples for PHREEQC Version 3: a computer program for speciation, batch-reaction, one-dimensional transport, and inverse geochemical calculations. (USGS Technical No. 6(A)43). U.S. Geological Survey, Denver, CO

Parkhurst DL, Wissmeier L (2015) PhreeqcRM: a reaction module for transport simulators based on the geochemical model PHREEQC. Adv Water Resour 83:176-189

Pedretti D (2020) Heterogeneity-controlled uncertain optimization of pump-and-treat systems explained through geological entropy. GEM Int J Geomath 11:22. https://doi.org/10.1007/s13137-02000158-8

Pedretti D, Bianchi M (2019) Preliminary results from the use of entrograms to describe transport in fractured media. Acque Sotter Ital J Groundw. https://doi.org/10.7343/as-2019-421

Pedretti D, Bianchi M (2018) Reproducing tailing in breakthrough curves: are statistical models equally representative and predictive? Adv Water Resour 113:236-248. https://doi.org/10.1016/j. advwatres.2018.01.023

Pedretti D, Mayer KU, Beckie RD (2017a) Stochastic multicomponent reactive transport analysis of low quality drainage release from waste rock piles: controls of the spatial distribution of acid generating and neutralizing minerals. J Contam Hydrol 201:30-38. https://doi.org/10.1016/j.jconhyd.2017.04.004

Pedretti D, Mayer KU, Beckie RD (2017b) Risk Assessment Of Acidic Drainage From Waste Rock Piles Using Stochastic Muticomponent Reactive Transport Modeling. In: Wolkersdorfer C, Sartz L, Sillanpää M, Häkkinen A (eds) Mine water \& circular economy. Finland (Lappeenranta University of Technology), Lappeenranta, pp 696-703

Pedretti D, Mayer KU, Beckie R.D (2016) Blending as an effective option to reduce the risk of water acidification from waste rock pile: a stochastic analysis, in: XXII International Conference of Computational Methods in Water Resources (CMWR) Toronto, Canada. p 67

Pedretti D, Mayer U, Beckie RD (2020) Controls of uncertainty in acid rock drainage predictions from waste rock piles examined through Monte-Carlo multicomponent reactive transport. Environ Res Risk Assess In press, Stoch. https://doi.org/10.1007/ s00477-019-01756-1

Peterson HE (2014) Unsaturated hydrology, evaporation, and geochemistry of neutral and acid rock drainage in highly heterogeneous mine waste rock at the Antamina Mine. Peru, Columbia

Plumlee GS (1999) The environmental geology of mineral deposits. Rev Econ Geol 6A:71-116

Price WA (2009) Prediction manual for drainage chemistry from sulphidic geologic materials. MEND report 1.1 NRC Canada

Renard P (2007) Stochastic hydrogeology: what professionals really need? Ground Water 45:531-541. https://doi.org/10.1111/j. 1745-6584.2007.00340.x

Renard P, Allard D (2013) Connectivity metrics for subsurface flow and transport. Adv Water Resour 51:168-196. https://doi.org/10. 1016/j.advwatres.2011.12.001

Richards LA (1931) Capillary conduction of liquids through porous mediums. Physics 1:318-333

Rimstidt JD, Vaughan DJ (2003) Pyrite oxidation: a state-of-the-art assessment of the reaction mechanism. Geochim. Cosmochim. Acta Adv Oxide Sulfide Miner Surf Chem 67:873-880. https:// doi.org/10.1016/S0016-7037(02)01165-1

Ritchie AIM (1977) Heap leaching: a gas diffusion rate-limited model. Australian Nuclear Science and Technology Organisation

Rolle M, Muniruzzaman M, Haberer CM, Grathwohl P (2013) Coulombic effects in advection-dominated transport of electrolytes in porous media: multicomponent ionic dispersion. Geochim Cosmochim Acta 120:195-205. https://doi.org/10. 1016/j.gca.2013.06.031

Rolle M, Sprocati R, Masi M, Biao J, Muniruzzaman M (2018) Nernst-planck-based description of transport, coulombic interactions, and geochemical reactions in porous media: modeling approach and benchmark experiments. Water Resour Res 54:3176-3195. https://doi.org/10.1002/2017WR022344

Rubin Y, Cushey MA, Bellin A (1994) Modeling of transport in groundwater for environmental risk assessment. Stoch Hydrol Hydraul 8:57-77. https://doi.org/10.1007/BF01581390

Russo D (2012) Numerical analysis of solute transport in variably saturated bimodal heterogeneous formations with mobile-immobile-porosity. Adv Water Resour 47:31-42. https://doi.org/10. 1016/j.advwatres.2012.05.017

Sanchez-Vila X, Fernàndez-Garcia D (2016) Debates: stochastic subsurface hydrology from theory to practice: why stochastic modeling has not yet permeated into practitioners? water resour. Res 52:9246-9258. https://doi.org/10.1002/2016WR019302

Sand W, Gerke T, Hallmann R, Schippers A (1995) Sulfur chemistry, biofilm, and the (in)direct attack mechanism: a critical evaluation of bacterial leaching. Appl Microbiol Biotechnol 43:961-966. https://doi.org/10.1007/BF00166909

Savage KS, Stefan D, Lehner SW (2008) Impurities and heterogeneity in pyrite: influences on electrical properties and oxidation products. Sulfide oxidation-sulfide oxidation: insights from experimental, theoretical, stable isotope, and predictive studies in the field and laboratory. Appl. Geochem 23:103-120. https:// doi.org/10.1016/j.apgeochem.2007.10.010

Sayab M, Suuronen J-P, Hölttä P, Aerden D, Lahtinen R, Kallonen AP (2015) High-resolution X-ray computed microtomography: a 
holistic approach to metamorphic fabric analyses. Geology 43:55-58. https://doi.org/10.1130/G36250.1

Schmidt MJ, Pankavich SD, Navarre-Sitchler A, Benson DA (2019) A Lagrangian method for reactive transport with solid/aqueous chemical phase interaction. J Comput Phys X 2:100021. https:// doi.org/10.1016/j.jcpx.2019.100021

Serre ML, Christakos G, Li H, Miller CT (2003) A BME solution of the inverse problem for saturated groundwater flow. Stoch Environ Res Risk Assess SERRA 17:354-369. https://doi.org/ 10.1007/s00477-003-0156-2

Servida D, Comero S, Dal Santo M, de Capitani L, Grieco G, Marescotti P, Porro S, Forray FL, Gál Á, Szakács A (2013) Waste rock dump investigation at Roşia Montană gold mine (Romania): a geostatistical approach. Environ Earth Sci 70:13-31. https://doi.org/10.1007/s12665-012-2100-6

Sheoran AS, Sheoran V (2006) Heavy metal removal mechanism of acid mine drainage in wetlands: a critical review. Miner Eng 19:105-116. https://doi.org/10.1016/j.mineng.2005.08.006

Simunek J, Jarvis NJ, van Genuchten MTh, Gärdenäs A (2003) Review and comparison of models for describing non-equilibrium and preferential flow and transport in the vadose zone. J Hydrol 272:14-35. https://doi.org/10.1016/S0022-1694(02)00252-4

Simunek JM, van Genuchten MTh, Sejna M (2005) The HYDRUS1D software package for simulating the one-dimensional movement of water, heat, and multiple solutes in variably-saturated media. University of California-Riverside Research Reports 3, California, pp 1-240

Smith JL, Beckie RD (2003) Hydrologic and geochemical transport processes in mine waste rock. In: Jambor JL, Blowes DW, Ritchie AIM (eds) Environmental aspects of mine wastes, short course series. Mineralogical Association of Canada, Ottawa, pp 51-72

Smith JL, Lopez DL, Beckie RD, Morin K, Dawson R, Price WA (1995) Hydrogeology of waste rock dumps, in Mine Environment Neutral Drainage (No PA-1). Natural Resources Canada, Ottawa, Canada

Sobek AA, Schuller WA, Freeman JR, Agency EP (1978) Field and laboratory methods applicable to overburdens and minesoils [www Document]. URL (accessed 7.24.15)

Southam G, Beveridge TJ (1993) Examination of lipopolysaccharide (O-Antigen) populations of thiobacillus ferrooxidans from two mine tailings. Appl Environ Microbiol 59:1283-1288

Sprocati R, Masi M, Muniruzzaman M, Rolle M (2019) Modeling electrokinetic transport and biogeochemical reactions in porous media: A multidimensional Nernst-Planck-Poisson approach with PHREEQC coupling. Adv Water Resour 127:134-147. https://doi.org/10.1016/j.advwatres.2019.03.011

Sracek O, Choquette M, Gélinas P, Lefebvre R, Nicholson RV (2004) Geochemical characterization of acid mine drainage from a waste rock pile, Mine Doyon, Québec. Can J Contam Hydrol 69:45-71. https://doi.org/10.1016/S0169-7722(03)00150-5

St-Arnault M, Vriens B, Blaskovich R, Aranda C, Klein B, Ulrich Mayer K, Beckie RD (2020) Geochemical and mineralogical assessment of reactivity in a full-scale heterogeneous waste-rock pile. Miner Eng 145:106089. https://doi.org/10.1016/j.mineng. 2019.106089

Steefel CI, Appelo CAJ, Arora B, Jacques D, Kalbacher T, Kolditz O, Lagneau V, Lichtner PC, Mayer KU, Meeussen JCL, Molins S, Moulton D, Shao H, Šimůnek J, Spycher N, Yabusaki SB, Yeh GT (2014) Reactive transport codes for subsurface environmental simulation. Comput Geosci. https://doi.org/10.1007/s10596014-9443-x

Strömberg B, Banwart S (1994) Kinetic modelling of geochemical processes at the Aitik mining waste rock site in northern Sweden. Appl Geochem 9:583-595. https://doi.org/10.1016/08832927(94)90020-5
Su D, Ulrich Mayer K, MacQuarrie KTB (2017) Parallelization of MIN3P-THCm: a high performance computational framework for subsurface flow and reactive transport simulation. Environ Model Softw 95:271-289. https://doi.org/10.1016/j.envsoft.2017.06.008

Tartakovsky DM (2013) Assessment and management of risk in subsurface hydrology: a review and perspective. Adv Water Resour 51:247-260. https://doi.org/10.1016/j.advwatres.2012.04.007

Tripathy DDP (2014) Prevention and treatment of acid mine drainage: an overview. https://doi.org/10.1007/978-81-322-1783-1_4

van der Sloot HA, van Zomeren A (2012) Characterisation leaching tests and associated geochemical speciation modelling to assess long term release behaviour from extractive wastes. Mine Water Environ 31:92-103. https://doi.org/10.1007/s10230-012-0182-8

van Genuchten MTh (1980) A closed-form equation for predicting the hydraulic conductivity of unsaturated soils1. Soil Sci Soc Am J 44:892. https://doi.org/10.2136/sssaj1980.036159950044000 $50002 x$

Vriens B, Peterson H, Laurenzi L, Smith L, Aranda C, Mayer KU, Beckie RD (2019) Long-term monitoring of waste-rock weathering at the Antamina mine, Peru. Chemosphere 215:858-869. https://doi.org/10.1016/j.chemosphere.2018.10.105

Wang H, Dowd PA, Xu C (2019) A reaction rate model for pyrite oxidation considering the influence of water content and temperature. Miner Eng 134:345-355. https://doi.org/10.1016/j. mineng.2019.02.002

Webb G, Tyler SW, Collord J, Van Zyl D, Halihan T, Turrentine J, Fenstemaker T (2008) Field-scale analysis of flow mechanisms in highly heterogeneous mining media. Vadose Zone $\mathrm{J}$ 7:899. https://doi.org/10.2136/vzj2007.0130

Weisener CG, Weber PA (2010) Preferential oxidation of pyrite as a function of morphology and relict texture. N Z J Geol Geophys 53:167-176. https://doi.org/10.1080/00288306.2010.499158

Wisotzky F (1994) Untersuchungen zur pyrotoxidation in sedimenten des rheinischen braunkohlenreviers und deren auswirkungen auf die chemie des grundwassers. Landesumweltamt NordrheinWestfalen

Wolkersdorfer C, Bowell R (2004) Contemporary reviews of mine water studies in europe, part 1. Mine Water Environ 23:162-182. https://doi.org/10.1007/s10230-004-0060-0

Wolkersdorfer C, Nordstrom DK, Beckie RD, Cicerone DS, Elliot T, Edraki M, Valente T, França SCA, Kumar P, Lucero RAO, Soler i Gil, A., (2020) Guidance for the Integrated Use of hydrological, geochemical, and isotopic tools in mining operations. Mine Water Environ. https://doi.org/10.1007/s10230-020-00666-x

Wright RO, Amarasiriwardena C, Woolf AD, Jim R, Bellinger DC (2006) Neuropsychological correlates of hair arsenic, manganese, and cadmium levels in school-age children residing near a hazardous waste site. NeuroToxicol 27:210-216. https://doi. org/10.1016/j.neuro.2005.10.001

Ye Z, Jiang Q, Yao C, Liu Y, Cheng A, Huang S, Liu Y (2018) The parabolic variational inequalities for variably saturated water flow in heterogeneous fracture networks. Geofluids 2018:1-16. https://doi.org/10.1155/2018/9062569

Yoon H, Kang Q, Valocchi AJ (2015) Lattice boltzmann-based approaches for pore-scale reactive transport. Rev Mineral Geochem 80:393-431. https://doi.org/10.2138/rmg.2015.80.12

Zhang C, Dehoff K, Hess N, Oostrom M, Wietsma TW, Valocchi AJ, Fouke BW, Werth CJ (2010) Pore-scale study of transverse mixing induced caco3 precipitation and permeability reduction in a model subsurface sedimentary system. Environ Sci Technol 44:7833-7838. https://doi.org/10.1021/es1019788

Publisher's Note Springer Nature remains neutral with regard to jurisdictional claims in published maps and institutional affiliations. 